\title{
Pengaruh kebijakan dividen, kebijakan leverage, keputusan investasi dan manajemen laba terhadap nilai perusahaan pertambangan yang terdaftar di BEI tahun 2015-2018
}

\author{
Siti Nurhasanatang, Taufeni Taufik, \& Nur Azlina*
}

Program Studi Akuntansi, Fakultas Ekonomi dan Bisnis, Universitas Riau, Indonesia

\begin{abstract}
Abstrak Penelitian ini bertujuan untuk mengetahui pengaruh kebijakan dividen, kebijakan leverage, keputusan investasi dan manajemen laba terhadap nilai perusahaan pertambangan yang terdaftar di BEI Tahun 2015-2018. Jumlah populasi sebanyak 41 perusahaan, sedangkan jumlah sampel dalam penelitian ini sebanyak 10 perusahaan dengan periode data selama 4 tahun, sehingga data yang akan disajikan menjadi 40 data. Penarikan sampel menggunakan metode purposive sampling sedangkan analisis data menggunakan regresi Linier Berganda. Hasil penelitian menyimpulkan bahwa variabel kebijakan dividen, kebijakan leverage, keputusan investasi dan manajemen laba berpengaruh terhadap nilai perusahaan, sedangkan berdasarkan hasil uji koefisien determinasi diperoleh nilai sebesar 75,1\%. Hal ini menunjukkan bahwa secara keseluruhan variabel berpengaruh terhadap nilai perusahaan sebesar 75,1\%, sedangkan sisanya sebesar 24,9\% dipengaruhi oleh variabel lain yang tidak diteliti dalam penelitian ini.
\end{abstract}

Kata kunci: nilai perusahaan; kebijakan dividen; kebijakan leverage; keputusan investasi, manajemen laba

\begin{abstract}
This research aims to the effect of dividend policy, leverage policy, investment decision, and earning management on value company of mining listed at Indonesia stock exchange in 2015-2018. The total population are 41 companies, while the sample size in this study is ten companies with a data period of 4 years so that the data will be presented as 40 data. Sampling uses a purposive sampling method, while data analysis uses Multiple Linear Regression. The results of the study concluded that the dividend policy variable, leverage policy, investment decisions and earnings management affect the value of the company, while based on the results of the coefficient of determination test obtained value of $75.1 \%$. This shows that overall the variables affect the firm value of $75.1 \%$, while the remaining $24.9 \%$ is influenced by other variables not examined in this research leverage.
\end{abstract}

Keywords: value of firms; dividend policy; leverage policy; invesment decision; earning management

JEL Classification: $G 32 ; D 25 ; G 11$ 


\section{PENDAHULUAN}

Perusahaan sektor pertambangan merupakan salah satu penopang pembangunan ekonomi suatu negara karena perannya sebagai penyedia sumber daya energi yang sangat diperlukan bagi pertumbuhan ekonomi. Industri pertambangan memerlukan biaya investasi yang sangat besar, jangka panjang, syarat risiko dan adanya ketidakpastian tinggi yang menjadikan masalah pendanaan sebagai isu utama terkait dengan pengembangan pertambangan. Untuk itu, perusahaan tambang banyak masuk ke pasar modal untuk menyerap investasi untuk memperkuat posisi keuangannya (Herliansyah, 2012).

Pada dasarnya perusahaan mempunyai tujuan jangka panjang yaitu mengoptimalkan dan memaksimalkan nilai perusahaan sehingga dapat memakmurkan para pemilik perusahaan. Dalam proses memaksimalkan nilai perusahaan, akan ada konflik antara kepentingan manajer dengan pemegang saham yang sering disebut dengan agency problem. Hal tersebut terjadi karena manajer mengutamakan kepentingan pribadi, sebaliknya pemegang saham tidak menyukai kepentingan pribadi dari manajer karena apa yang dilakukan manajer tersebut akan menambah biaya bagi perusahaan sehingga menyebabkan penurunan keuntungan perusahaan dan berpengaruh terhadap harga saham yang dapat menurunkan nilai perusahaan (Jensen \& Meckling, 1976).

Menurut Sartono (2010), nilai perusahaan adalah nilai jual sebuah perusahaan sebagai suatu bisnis yang sedang beroperasi. Adanya kelebihan nilai jual di atas nilai likuidasi adalah nilai dari organisasi manajemen yang menjalankan perusahaan itu. Fenomena terpuruknya harga saham perusahaan tambang yang mempengaruhi nilai perusahaan telah terjadi sejak tahun 2015. Di awal tahun, indeks saham sektor pertambangan sempat berada dilevel 1.368 namun terus mengalami penurunan hingga menyentuh level terendah di posisi 855. Terakhir, indeks harga saham pertambangan berada di posisi 941,74. Kondisi ini dinilai mempengaruhi nilai perusahaan karena nilai perusahaan sendiri tercermin dari harga sahamnya (lka, 2015).

Selanjutnya hasil riset Pricewaterhouse Coopers (PwC) pada tahun 2016 menyebutkan sebanyak 40 perusahaan tambang global mengalami kerugian terbesar sepanjang sejarah selama 2015. Pada tahun itu, mereka mengalami kerugian 27 miliar dollar AS atau setara sekitar Rp 364,5 triliun dengan kurs Rp 13.500 per dollar AS. Pada tahun ini, harga komoditas tambang pun kembali turun $25 \%$ dibanding tahun lalu. Krisis global ini terjadi karena aksi melepas saham oleh para investor yang menilai bahwa industri pertambangan tidak prospektif untuk mengambil keuntungan (Gewati, 2016).

Pada tahun 2017, rencana pengaturan harga jual khusus batu bara ke sektor ketenagalistrikan mendorong indeks sektor pertambangan memerah. Tercatat bahwa indeks sektor pertambangan mengalami penurunan paling tajam dibandingkan dengan sektor lainnya. Penurunan laba juga dialami oleh PT. PLN yang menyebabkan tertundanya pembagian dividen. Sementara itu, kepala Badan Pusat Statistik (BPS) Suhariyanto menyebutkan "sektor pertambangan dan 
penggalian merupakan satu-satunya sektor yang mengalami kontraksi negatif 0,49 persen. Ini juga karena penurunan produksi tembaga dan emas oleh PT Freeport Indonesia dan PT Amman" (Fauzi, 2017).

Terakhir pada tahun 2018, Kementerian Energi dan Sumber Daya Mineral mencatat realisasi investasi di tahun 2018 mencapai USD 6,8 miliar. Angka tersebut hanya tumbuh sedikit dibandingkan target yang sudah ditetapkan dalam APBN 2018 sebesar USD 6,2 miliar. Direktur Jenderal Mineral dan Batu Bara Kementerian ESDM, Bambang Gatot mengatakan bahwa tidak timbulnya investasi disektor pertambangan karena memang belum ada investor baru yang datang. Sehingga tambang yang beroperasi bukan tambang baru, melainkan tambang lama yang produksinya sudah berjalan (Hartomo, 2019).

Teori agensi ini merupakan teori yang menjelaskan tentang hubungan kerja antara pemilik perusahaan (pemegang saham) dan manajemen. Manajemen sendiri adalah agen yang ditunjuk oleh pemegang saham yang diberi tugas dan wewenang mengelola perusahaan atas nama pemegang saham. Jensen dan Meckling (1976) mengatakan bahwa potensi konflik agensi akan muncul apabila dari $100 \%$ saham biasa perusahaan yang mendorong manajer untuk memaksimalkan keuntungan sendiri. Hal ini dapat terjadi karena adanya pemisahan kekuasaan antara fungsi pengelola dan fungsi kepemilikan. Apabila manajer salah dalam mengambil keputusan maka pemegang sahamlah yang menerima dampaknya. Dampak ini dapat berupa tingkat pengembalian dividen atau nilai perusahaan menurun yang menyebabkan harga saham ikut menurun dalam pasar saham yang dapat mempengaruhi tindakan investor lainnya dalam menyikapi masalah tersebut.

Teori sinyal (signalling theory) adalah suatu teori yang berhubungan dengan pendapat investor dalam memandang prospoek atau kinerja perusahaan yang akan dipilih dalam menanamkan dananya. Teori sinyal mengemukakan tentang bagaimana seharusnya sebuah perusahaan memberikan sinyal kepada pengguna laporan keuangan. Teori ini juga merupakan suatu perilaku manajemen perusahaan dalam memberi petunjuk untuk investor terkait pandangan manajemen pada prospek perusahaan untuk masa mendatang (Brigham \& Houston, 2014).

Teori bird in the hand adalah salah satu kebijakan dividen, teori ini dikembangkan Lintner (1956). Lintner menyatakan bahwa ada hubungan antara nilai perusahaan dengan kebijakan dividen, biaya modal sendiri perusahaan akan naik jika dividend payout ratio rendah karena investor lebih suka menerima dividen dibandingkan capital gain. Alasan yang sering dikemukakan dalam memilih teori bird in the hand ini karena ada anggapan bahwa mendapat dividen tinggi saat ini resikonya lebih kecil daripada mendapat capital gain dimasa yang akan datang. Dalam teori ini dijelaskan bahwa investor menghendaki pembayaran dividen yang tinggi dari keuntungan perusahaan sesuai tujuan investor yaitu menanamkan sahamnya untuk mendapatkan dividen, investor tidak ingin berinvestasi di perusahaan jika penerimaan dividen dalam jangka waktu yang lama.

Menurut Sartono (2010), nilai perusahaan adalah nilai jual sebuah perusahaan sebagai suatu bisnis yang sedang beroperasi. Martono \& Harjito (2010) menambahkan bahwa nilai perusahaan adalah suatu kegiatan memaksimumkan 
kemakmuran pemegang saham (stockholder wealth maximation) yang dapat diartikan juga sebagai memaksimumkan harga saham biasa dari perusahaan (maximizing the price of the firm's common stock).

Variabel independent pertama dalam penelitian ini yaitu kebijakan dividen yang merupakan salah satu fungsi manajemen keuangan yang berkaitan erat dengan struktur modal perusahaan. Kebijakan dividen adalah kebijakan yang bersangkutan dengan penentuan pembagian pendapatan (earning) antara pengguna pendapatan untuk dibayarkan kepada pemegang saham sebagai dividen atau untuk digunakan dalam perusahaan, yang berarti bahwa pendapatan tersebut harus ditanam di dalam perusahaan. Apabila perusahaan memilih untuk menahan laba yang diperoleh maka kemampuan pembentukan dana intern akan semakin besar (Riyanto, 2011). Manurung (2012) mengatakan bahwa kebijakan dividen menyangkut tentang masalah penggunaan laba yang menjadi hak pemegang saham. Pada dasarnya, laba tersebut dibagi sebagai dividen atau ditahan untuk diinvestasikan kembali.

Variabel kedua, kebijakan leverage adalah kebijakan yang diambil pihak manajemen dalam rangka memperoleh sumber pembiayaan bagi perusahaan sehingga dapat digunakan untuk membiayai aktivitas operasional perusahaan (Riyanto, 2011). Pada umumnya ada dua jenis leverage, yaitu leverage operasi (operating leverage) dan leverage keuangan (financial leverage). Leverage yang dimaksud dalam penelitian ini adalah leverage keuangan yang menunjukkan proporsi atas penggunaan utang untuk membiayai investasinya. Pihak-pihak yang mempertimbangkan untuk berinvestasi kepada suatu perusahaan akan tertarik dengan struktur leverage dari perusahaan tersebut. Riyanto (2011) menambahkan kebijakan leverage merupakan keputusan yang sangat penting dalam perusahaan. Dimana kebijakan ini juga merupakan salah satu bagian dari kebijakan pendanaan perusahaan. Menurut Brigham dan Houston (2011) menyatakan kebijakan hutang (leverage) adalah kebijakan mengenai keputusan yang diambil perusahaan untuk menjalankan operasionalnya dengan menggunakan hutang atau financial leverage.

Variabel ketiga, keputusan investasi adalah keputusan sebagai komposisi antara aset yang dimiliki dan pilihan investasi dimasa yang akan datang (Wijaya \& Wibawa, 2010).Keputusan investasi ini melibatkan waktu jangka panjang sehingga keputusan yang diambil harus dipertimbangkan dengan baik, karena memiliki konsekuensi berjangka pula. Selain itu, keputusan investasi berkaitan dengan proses pemilihan satu atau lebih alternatif investasi yang tersedia dan dinilai menguntungkan bagi perusahaan. Menurut Martono dan Harjito (2010), keputusan investasi adalah keputusan terhadap aset apa yang akan dikelola oleh perusahaan. keputusan investasi berpengaruh secara langsung terhadap besarnya rentabilitas investasi dan airan kas perusahaan untuk waktu yang akan datang.

Variabel terakhir, manajemen laba adalah tindakan-tindakan manajer untuk menaikkan (menurunkan) laba periode berjalan dari sebuah perusahaan yang dikelolanya tanpa menyebabkan kenaikan (penurunan) keuntungan ekonomi perusahaan jangka panjang (Fischer \& Rosenzweig, 1995). Laba telah menjadi indikator umum bagi pihak manajemen dan pihak eksternal untuk menilai kinerja 
perusahaan dalam membuat keputusan investasi. Sampai saat ini, manajemen laba merupakan area yang paling kontroversial dalam akuntansi keuangan. Schipper (1989) menyatakan bahwa manajemen laba merupakan suatu intervensi dengan tujuan tertentu dalam proses pelaporan eksternal, utnuk memperoleh beberapa keuntungan privat (sebagai lawan untuk memudahkan operasi yang netral dari proses tersebut).

Alasan penulis meneliti kembali variabel independen (kebijakan dividen, kebijakan leverage, keputusan investasi dan manajemen laba) karena masih terdapat variabel yang belum konsisten hasilnya. Selain itu, menurut penulis dari keempat variabel tersebut memiliki peranan penting dalam meningkatkan nilai perusahaan.

Berdasarkan hal tersebut, maka tujuan penelitian ini adalah untuk mengetahui pengaruh kebijakan dividen, kebijakan leverage, keputusan investasi, dan manajemen laba terhadap nilai perusahaan.

\section{METODE PENELITIAN}

\section{Penarikan Sampel}

Penelitian ini menggunakan metode kuantitatif. Populasi dalam penelitian ini adalah perusahaan pertambangan yang terdaftar di BEl tahun 2015-2018 yang diperoleh melalui situs www.sahamok.com. Sampel dalam penelitian ini sebanyak 10 perusahaan yang diperoleh melalui situs www.eddyelly.com. Penarikan sampel dilakukan dengan metode purposive sampling. Sedangkan jenis data yang digunakan adalah data sekunder yang diperoleh melalui situs www.idx.co.id.

\section{Pengolahan Data}

Rumus pengukuran yang digunakan dalam penelitian ini adalah Tobin's $Q$ yang dikembangkan oleh James Tobin. Tobin's $Q$ dihitung dengan membandingkan rasio nilai pasar saham perusahaan dengan nilai bku ekuitas perusahaan. Rumus dari Tobin's $Q$ adalah:

$$
D=\frac{D(E M V+D)}{(E B D+D)}
$$

Rumus pengukuran yang digunakan dalam penelitian ini adalah Dividen Paout Ratio (DPR). Rasio ini merupakan rasio hasil perbandingan antara dividen dengan laba yang tersedia bagi pemegang saham biasa. Secara sistematis, dapat dirumuskan sebagai berikut:

$$
D P R=\frac{\text { dividend per share }}{\text { earning per share }}
$$

Adapun rasio yang umum digunakan dalam mengukur kebijakan leverage adalah debt ratio (debt to total asset ratio), rasio ini memperlihatkan proporsi antara kewajiban yang dimiliki dan seluruh kekayaan yang dimiliki. Berikut rumus pengukurannya: 


$$
\text { Debt ratio }=\frac{\text { Total debt }}{\text { Total assets }}
$$

Adapun proksi pengukuran yang digunakan dalam penelitian ini adalah price earning ratio (PER). Price earning ratio (PER) adalah nilai harga per lembar saham. Berikut adalah rumus pengukuran dari price earning ratio (PER):

$$
\text { Price earning ratio }=\frac{\text { Harga saham }}{\text { Penghasilan per saham }}
$$

Rumus pengukuran manajemen laba menggunakan discretinary accrual (DAC). Untuk mengukur DAC, terlebih dahulu akan mengukur total akrual. Total akrual diklasifikasikan menjadi komponen discretionary dan non-discretionary. Dengan tahapan:

a. Mengukur total accrual dengan menggunakan model Jones yang dimodifikasi

Total accrual $(\mathrm{TAC})=$ laba bersih setelah pajak (net income) - arus kas operasi (cash flow from operating)

b. Menghitung nilai accrual yang diestimasi dengan persamaan OLS (ordinary least square):

$T A C t / A t-1=\alpha 1(1 / A t-1)+\alpha 2((\Delta R E V t-\triangle R E C t) / A t-1)+\alpha 3(P P E t / A t-1)+e$

TACt : total accrual perusahaan i pada periode $t$

At-1 : total aset untuk sampel perusahaan i pada akhir tahun t-1

REVt : perubahan pendapatan perusahaan i dari tahun $\mathrm{t}-1$ ke tahun $\mathrm{t}$

RECt : perubahan piutang perusahaan i dari tahun $\mathrm{t}-1$ ke tahun $\mathrm{t}$

PPEt : aktiva tetap (gross property plant and equipment) perusahaan tahun $t$

c. Menghitung non-discretionary accruals model (NDA) adalah sebagai berikut:

$$
\mathrm{NDAt}=\alpha 1(1 / \mathrm{At}-1)+\alpha 2((\Delta \mathrm{REVt}-\Delta \mathrm{RECt}) / \mathrm{At}-1)+\alpha 3(\mathrm{PPEt} / \mathrm{At}-1)
$$

NDAt : Non-discretionary accrual pada tahun t.

A : fitted coeffivient yang diperoleh dari hasil regresi pada perhitungan total accruals.

d. Menghitung discretionary accruals.

$$
\text { DACt }=(\text { TACt } / \text { At-1) }- \text { NDAt }
$$

DACt : discretionary accruals perusahaan i pada periode t.

\section{Pengumpulan dan Analisis Data}

Teknik pengumpulan data dilakukan dengan metode kepustakaan (buku, skripsi, jurnal maupun tesis) dan komputer (situs-situs internet dan laporan-laporan $\mathrm{BEI})$. Metode analisis data yang digunakan yaitu analisis deskriptif, uji asumsi klasik (uji normalitas, uji multikolinieritas, uji autokorelasi dan uji heteroskedastisitas) dan regresi linier berganda. Pengujian hipotesis dilakukan dengan menggunakan uji $t$ dan uji koefisien determinasi (R2). Adapun model penlitian yang akan diuji pada penelitian ini dapat dilihat pada Gambar 1. 


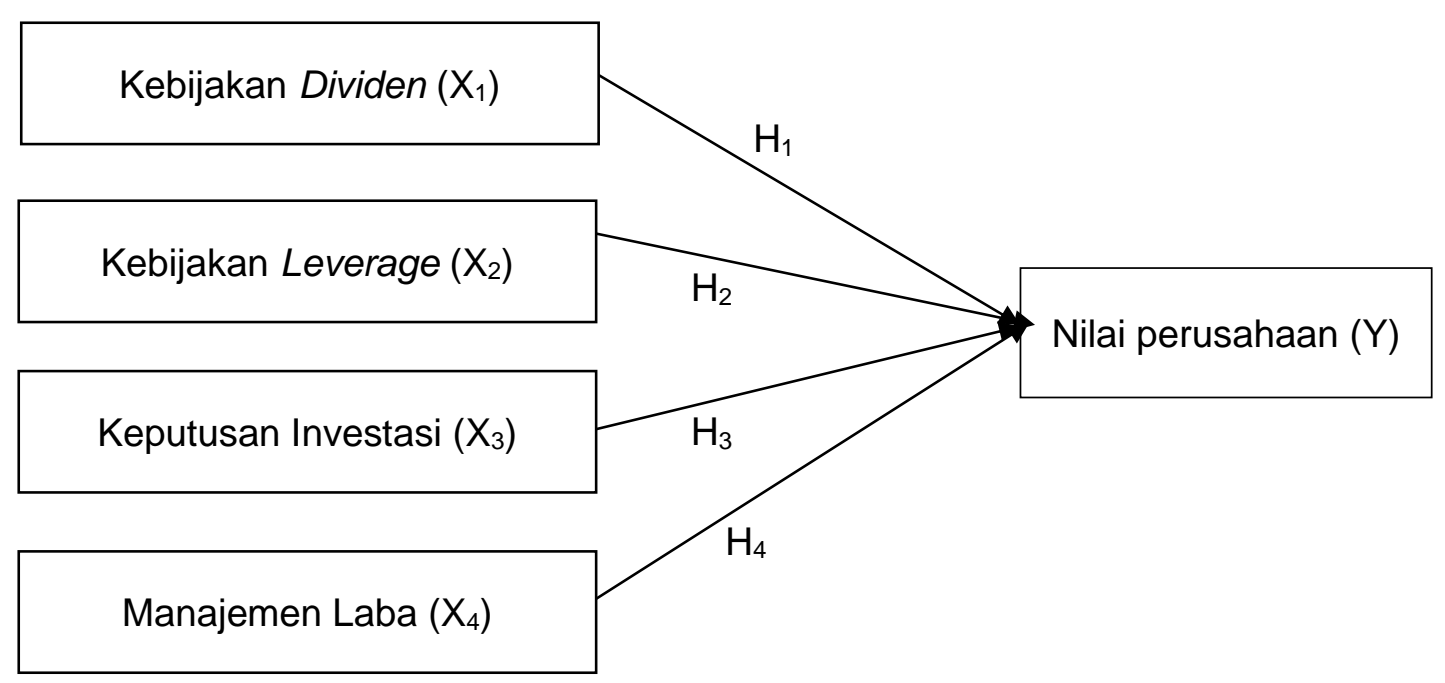

Gambar 1. Model penelitian

\section{HASIL DAN PEMBAHASAN}

\section{Hasil Analisis Deskriptif}

\section{Nilai Perusahaan}

Pada Tabel 1, dari 10 perusahaan sampel yang memiliki nilai perusahaan di bawah rata-rata sebanyak 6 perusahaan, diantaranya: Adaro Energy Tbk, Baramulti Suksessarana Tbk, Golden Energy Mines Tbk, Indo Tambangraya Megah Tbk, Timah (Persero) Tbk dan Radiant Utama Interiso Tbk. Sedangkan perusahaan yang memiliki nilai perusahaan di atas rata-rata sebanyak 4 perusahaan, diantaranya: Samindo Resources Tbk, Tambang Batubara Bukit Asam (Persero) Tbk, Mitrabara Adiperdana Tbk dan Elnusa Tbk.

Tabel 1. Hasil Uji Secara Deskriptif Variabel Nilai Perusahaan (Milyar Rupiah)

\begin{tabular}{clrrrrr}
\hline No & Nama Emiten & $\mathbf{2 0 1 5}$ & $\mathbf{2 0 1 6}$ & $\mathbf{2 0 1 7}$ & $\mathbf{2 0 1 8}$ & Mean \\
\hline \multirow{2}{*}{1} & Adaro Energy Tbk & 1,00000000 & 1,00000000 & 1,00000000 & 1,0000000 & 1,0000000 \\
& Baramulti & 35 & 34 & 034 & 035 \\
2 & 1,00000000 & 1,00000000 & 1,00000000 & 1,0000000 & 1,0000000 \\
& Suksessarana Tbk & 56 & 56 & 55 & 054 & 055 \\
& Golden Energy & 1,00000000 & 1,00000000 & 1,00000000 & 1,0000000 & 1,0000000 \\
3 & Mines Tbk & 71 & 70 & 68 & 066 & 069 \\
& $\begin{array}{l}\text { Indo Tambangraya } \\
4\end{array}$ & 1,00000000 & 1,00000000 & 1,00000000 & 1,0000000 & 1,0000000 \\
& Megah Tbk & 74 & 73 & 72 & 069 & 072 \\
5 & Samindo Resources & 1,00000001 & 1,00000001 & 1,00000001 & 1,0000000 & 1,0000000 \\
& Tbk & 22 & 20 & 15 & 109 & 117 \\
& Tambang Batubara & 1,00000001 & 1,00000001 & 1,00000001 & 1,0000000 & 1,0000000 \\
6 & Bukit Asam & 16 & 14 & 10 & 104 & 111 \\
& (Persero) Tbk & & & & & \\
7 & Timah (Persero) & 1,00000000 & 1,00000000 & 1,00000000 & 1,0000000 & 1,0000000 \\
& Tbk & 81 & 80 & 78 & 075 & 078 \\
8 & Radiant Utama & 1,00000000 & 1,00000000 & 1,00000000 & 1,0000000 & 1,0000000 \\
& Interinsco Tbk & 31 & 31 & 30 & 030 & 030 \\
9 & Mitrabara & 1,00000001 & 1,00000001 & 1,00000001 & 1,0000000 & 1,0000000 \\
& Adiperdana Tbk & 12 & 10 & 06 & 101 & 107
\end{tabular}




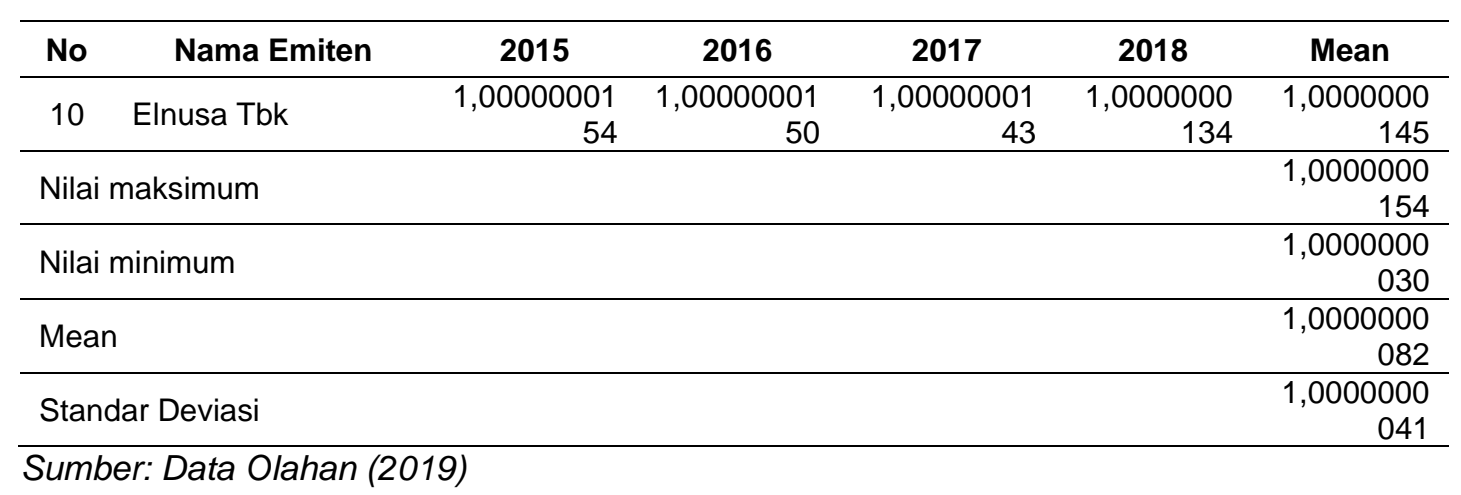

\section{Kebijakan Deviden}

Hasil analisis deskriptif kebijakan dividen dapat dilihat pada Tabel 2. Dari 10 perusahaan sampel yang memiliki nilai kebijakan dividen di bawah rata-rata sebanyak 7 perusahaan, diantaranya: Baramulti Suksessarana Tbk, Golden Energy Mines Tbk, Indo Tambangraya Megah Tbk, Samindo Resources Tbk, Tambang Batubara Bukit Asam (Persero) Tbk, Timah (Persero) Tbk dan Elnusa Tbk. Sedangkan perusahaan yang memiliki nilai kebijakan dividen diatas rata-rata sebanyak 3 perusahaan, diantaranya: Radiant Utama Interinsco Tbk dan Mitrabara Adiperdana Tbk dan Adaro Energy Tbk.

Tabel 2. Hasil Uji Secara Deskriptif Variabel Kebijakan Dividen

\begin{tabular}{|c|c|c|c|c|c|c|}
\hline No & Nama Emiten & 2015 & 2016 & 2017 & 2018 & Mean \\
\hline 1 & Adaro Energy Tbk & 0,30 & 0,30 & 0,30 & 0,30 & 0,30 \\
\hline 2 & $\begin{array}{l}\text { Baramulti Suksessarana } \\
\text { Tbk }\end{array}$ & 0,14 & 0,15 & 0,15 & 0,15 & 0,15 \\
\hline 3 & Golden Energy Mines Tbk & 0,17 & 0,17 & 0,17 & 0,17 & 0,17 \\
\hline 4 & $\begin{array}{l}\text { Indo I ambangraya IMegan } \\
\text { Tbk }\end{array}$ & 0,20 & 0,20 & 0,20 & 0,20 & 0,20 \\
\hline 5 & Samindo Resources Tbk & 0,15 & 0,15 & 0,15 & 0,15 & 0,15 \\
\hline 6 & $\begin{array}{l}\text { Tambang Batubara Bukit } \\
\text { Asam (Persero) Tbk }\end{array}$ & 0,15 & 0,15 & 0,15 & 0,15 & 0,15 \\
\hline 7 & Timah (Persero) Tbk & 0,20 & 0,20 & 0,20 & 0,20 & 0,20 \\
\hline 8 & $\begin{array}{l}\text { Radiant Utama Interinsco } \\
\text { Tbk }\end{array}$ & 0,35 & 0,35 & 0,35 & 0,35 & 0,35 \\
\hline 9 & Mitrabara Adiperdana Tbk & 0,25 & 0,25 & 0,25 & 0,25 & 0,25 \\
\hline 10 & Elnusa Tbk & 0,15 & 0,15 & 0,15 & 0,15 & 0,15 \\
\hline \multicolumn{6}{|c|}{ Nilai maksimum } & 0,35 \\
\hline \multicolumn{6}{|c|}{ Nilai minimum } & 0,14 \\
\hline \multirow{2}{*}{\multicolumn{6}{|c|}{ Mean }} & 0,21 \\
\hline & & & & & & 0,11 \\
\hline
\end{tabular}

\section{Kebijakan Leverage}

Hasil analisis deskriptif kebijakan leverage dapat dilihat pada Tabel 3. Dari 10 perusahaan sampel yang memiliki nilai kebijakan leverage di bawah rata-rata 
sebanyak 5 perusahaan, diantaranya: Baramulti Suksessarana Tbk, Samindo Resources Tbk, Tambang Batubara Bukit Asam (Persero) Tbk, Timah (Persero) Tbk, dan Mitrabara Adiperdana Tbk. Sedangkan perusahaan yang memiliki nilai kebijakan leverage di atas rata-rata sebanyak 5 perusahaan, diantaranya: Adaro Energy Tbk, Golden Energy Mines Tbk, Indo Tambangraya Megah Tbk, Radiant Utama Interinsco Tbk dan Elnusa Tbk.

Tabel 3. Hasil Uji Secara Deskriptif Variabel Kebijakan Leverage

\begin{tabular}{|c|c|c|c|c|c|c|}
\hline No & Nama Emiten & 2015 & 2016 & 2017 & 2018 & Mean \\
\hline 1 & Adaro Energy Tbk & 0,08 & 0,08 & 0,08 & 0,08 & 0,08 \\
\hline 2 & $\begin{array}{l}\text { Baramulti Suksessarana } \\
\text { Tbk }\end{array}$ & 0,04 & 0,04 & 0,04 & 0,04 & 0,04 \\
\hline 3 & \multirow{2}{*}{$\begin{array}{l}\text { Golden Energy Mines Tbk } \\
\text { Indo Tambangraya Megah } \\
\text { Tbk }\end{array}$} & 0,09 & 0,09 & 0,09 & 0,09 & 0,09 \\
\hline 4 & & 0,07 & 0,07 & 0,07 & 0,07 & 0,07 \\
\hline 5 & \multirow{2}{*}{$\begin{array}{l}\text { Samindo Resources Tbk } \\
\text { Tambang Batubara Bukit } \\
\text { Asam (Persero) Tbk }\end{array}$} & 0,02 & 0,02 & 0,02 & 0,02 & 0,02 \\
\hline 6 & & 0,04 & 0,04 & 0,04 & 0,05 & 0,04 \\
\hline 7 & Timah (Persero) Tbk & 0,04 & 0,04 & 0,04 & 0,04 & 0,04 \\
\hline 8 & $\begin{array}{l}\text { Radiant Utama Interinsco } \\
\text { Tbk }\end{array}$ & 0,12 & 0,13 & 0,13 & 0,13 & 0,13 \\
\hline 9 & Mitrabara Adiperdana Tbk & 0,06 & 0,06 & 0,06 & 0,06 & 0,06 \\
\hline 10 & Elnusa Tbk & 0,17 & 0,17 & 0,18 & 0,19 & 0,17 \\
\hline \multicolumn{2}{|c|}{ Nilai maksimum } & & & & & 0,19 \\
\hline \multicolumn{2}{|c|}{ Nilai minimum } & & & & & 0,02 \\
\hline \multirow{2}{*}{\multicolumn{2}{|c|}{ Mean }} & & & & & 0,07 \\
\hline & & & & & & 0.03 \\
\hline
\end{tabular}

\section{Keputusan Investasi}

Hasil analisis deskriptif keputusan investasi dapat dilihat pada Tabel 4. Dari 10 perusahaan sampel yang memiliki nilai keputusan investasi dibawah rata-rata sebanyak 1 perusahaan, diantaranya Adaro Energy Tbk. Sedangkan perusahaan yang memiliki nilai keputusan investasi di atas rata-rata sebanyak 9 perusahaan, diantaranya Baramulti Suksessarana Tbk, Golden Energy Mines Tbk, Indo Tambangraya Megah Tbk, Samindo Resources Tbk, Tambang Batubara Bukit Asam (Persero) Tbk, Timah (Persero) Tbk, Radiant Utama Interinsco Tbk, Mitrabara Adiperdana Tbk dan Elnusa Tbk.

Tabel 4. Hasil Uji Secara Deskriptif Variabel Keputusan Investasi

\begin{tabular}{clccccc}
\hline No & Nama Emiten & $\mathbf{2 0 1 5}$ & $\mathbf{2 0 1 6}$ & $\mathbf{2 0 1 7}$ & $\mathbf{2 0 1 8}$ & Mean \\
\hline 1 & Adaro Energy Tbk & 3,00 & 3,00 & 3,00 & 3,00 & 3,00 \\
2 & Baramulti Suksessarana Tbk & 3,71 & 3,71 & 3,71 & 3,71 & 3,71 \\
3 & Golden Energy Mines Tbk & 3,71 & 3,71 & 3,71 & 3,71 & 3,71 \\
4 & Indo Tambangraya Megah & 3,63 & 3,63 & 3,63 & 3,63 & 3,63
\end{tabular}




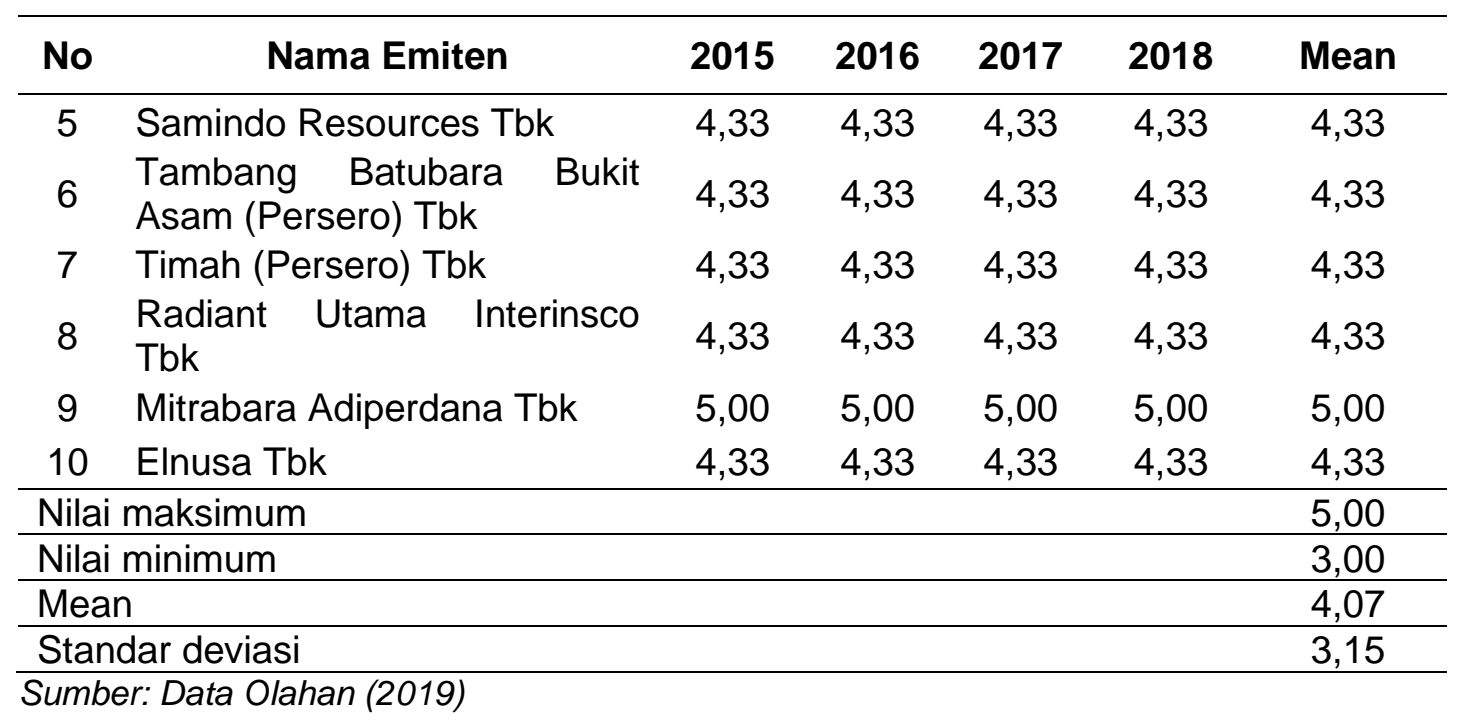

\section{Manajemen Laba}

Selanjutnya hasil analisis deskriptif manajemen laba dapat dilihat pada Tabel 5. Dari 10 perusahaan sampel yang memiliki nilai manajemen laba di bawah rata-rata sebanyak 6 perusahaan, diantaranya: Golden Energy Mines Tbk, Samindo Resources Tbk, Tambang Batubara Bukit Asam (Persero) Tbk, Timah (Persero) Tbk, Mitrabara Adiperdana Tbk dan Elnusa Tbk. Sedangkan perusahaan yang memiliki nilai manajemen laba di atas rata-rata sebanyak 4 perusahaan, diantaranya: Adaro Energy Tbk, Baramulti Suksessarana Tbk, Indo Tambangraya Megah Tbk dan Radiant Utama Interinsco Tbk.

Tabel 5. Hasil Uji Secara Deskriptif Variabel Manajemen Laba

\begin{tabular}{clrrrrr}
\hline No & Nama Emiten & $\mathbf{2 0 1 5}$ & $\mathbf{2 0 1 6}$ & $\mathbf{2 0 1 7}$ & \multicolumn{1}{c}{$\mathbf{2 0 1 8}$} & \multicolumn{1}{c}{ Mean } \\
\hline 1 & Adaro Energy & 1.386 .776 .6 & 1.386 .982 & 1.387 .160 & 1.387 .060$. & 1.386 .995 .1 \\
& Tbk & 99.500 & .914 .000 & .437 .250 & 437.450 & 22.050 \\
2 & Baramulti & 988.293 .96 & 988.500 .1 & $988.677,7$ & 988.577 .7 & 988.512 .38 \\
& Suksessarana & 5.500 & 80.000 & 03.250 & 03.450 & 8.050 \\
& Tbk & & & & \\
3 & Golden Energy & 632.000 .00 & 632.206 .2 & 632.383 .7 & 632.283 .7 & 632.218 .42 \\
& Mines Tbk & 0.000 & 14.000 & 37.250 & 37.450 & 2.175 \\
4 & Indo & 790.000 .05 & 790.206 .2 & 790.383 .7 & 790.283 .7 & 790.218 .48 \\
& Tambangraya & 8.000 & 72.000 & 95.250 & 95.450 & 0.175 \\
& Megah Tbk & 470.000 .00 & 470.206 .2 & 470.383 .7 & 470.283 .7 & 470.218 .42 \\
5 & Samindo & 0.000 & 14.300 & 37.550 & 37.750 & 2.400 \\
& Resources Tbk & & & & & \\
6 & Tambang & & & & \\
& Batubara Bukit & 610.000 .00 & 610.206 .2 & 610.383 .7 & 610.283 .7 & 610.218 .42 \\
& Asam (Persero) & 0.000 & 14.500 & 37.750 & 37.950 & 2.550 \\
& Tbk & & & & & \\
7 & Timah (Persero) & 420.000 .09 & 420.206 .3 & 420.383 .8 & 420.283 .8 & 420.218 .51 \\
& Tbk & 2.000 & 06.000 & 29.250 & 29.450 & 4.175 \\
8 & Radiant Utama & $1.090 .000,0$ & 1.090 .206 & 1.090 .383 & 1.090 .283$. & 1.090 .218 .5 \\
& Interinsco Tbk & 98.000 & .312 .000 & .835 .250 & 835.450 & 20.175 \\
9 & Mitrabara & 410.000 .05 & 410.206 .2 & 410.383 .7 & 410.283 .7 & 410.218 .48 \\
& Adiperdana Tbk & 8.000 & 72.000 & 95.250 & 95.450 & 0.175
\end{tabular}




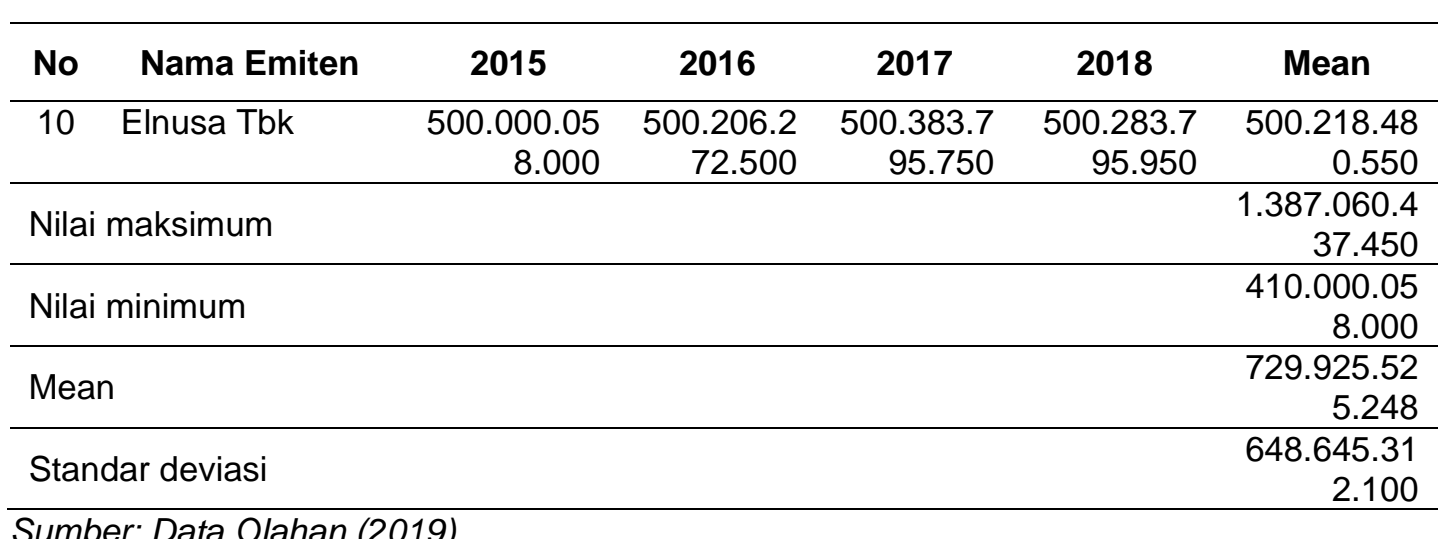

\section{Hasil Uji Asumsi Klasik}

\section{Hasil Uji Normalitas}

Berdasarkan Tabel 6 dapat dilihat bahwa nilai Asymp. Sig. (2-tailed) yang dihasilkan sebesar 0,402 dimana nilai ini lebih besar dari 0,05. Maka distribusi data dinyatakan memenuhi asumsi normalitas.

Tabel 6. Rekapitulasi Hasil Normalitas

\begin{tabular}{|c|c|c|}
\hline \multicolumn{3}{|c|}{ One-Sample Kolmogorov-Smirnov Test } \\
\hline & & Unstandardized Residual \\
\hline \multicolumn{2}{|c|}{$\mathrm{N}$} & 40 \\
\hline \multirow{2}{*}{$\begin{array}{c}\text { Normal } \\
\text { Parameters }\end{array}$} & Mean & .1327520 \\
\hline & Std. Deviation & 2.21247907 \\
\hline \multirow{3}{*}{$\begin{array}{l}\text { Most Extreme } \\
\text { Differences }\end{array}$} & Absolute & .063 \\
\hline & Positive & .047 \\
\hline & Negative & -.064 \\
\hline \multicolumn{2}{|c|}{ Kolmogorov-Smirnov Z } & 1.353 \\
\hline \multicolumn{2}{|c|}{ Asymp. Sig. (2-tailed) } & .402 \\
\hline
\end{tabular}

a. Test distribution is Normal.

Sumber: Data Olahan SPSS (2019)

\section{Hasil Uji Multikolinearitas}

Berdasarkan Tabel 7 dapat dilihat bahwa nilai VIF untuk variabel kebijakan dividen sebesar 3.744, kemudian nilai VIF untuk variabel kebijakan leverage sebesar 2.730, selanjutnya nilai VIF untuk variabel keputusan investasi sebesar 7.307 dan nilai VIF untuk variabel manajemen laba sebesar 8.545. Sehingga dapat disimpulkan bahwa model regresi dalam penelitian ini bebas dari multikoliearitas hal ini dikarenakan nilai VIF $<10$. 
Tabel 7. Hasil Uji Multikolinearitas

\begin{tabular}{llll}
\hline \multicolumn{4}{c}{ Coefficients $^{\mathbf{a}}$} \\
\cline { 2 - 4 } Model & \multicolumn{2}{c}{ Collinearity Statistics } \\
\cline { 2 - 4 } Tolerance & VIF \\
\hline $1 \quad$ Constant $)$ & .093 & 3.744 \\
Kebijakan Dividen & .129 & 2.730 \\
Kebijakan Leverage & .120 & 7.307 \\
Keputusan Investasi & .393 & 8.545 \\
\multicolumn{2}{l}{ Manajemen Laba } & &
\end{tabular}

a. Dependent Variable: Nilai perusahaan Sumber: Data Olahan (2019)

\section{Hasil Uji Autokorelasi}

Tabel 8 memperlihatkan bahwa nilai D-W untuk ketiga variabel independen sebesar 1,201. Hal ini menunjukkan nilai D-W berada diantara -2 sampai +2 , yang artinya tidak ada autokorelasi. Dengan demikian dapat disimpulkan bahwa tidak ada autokorelasi dalam model penelitian ini.

Tabel 8. Uji Autokorelasi

\begin{tabular}{ll}
\hline \multicolumn{2}{c}{ Model Summary $^{\mathbf{b}}$} \\
\hline Model Durbin-Watson & 1.201 \\
\hline 1 & \\
a. Predictors: (Constant), Manajemen Laba, Kebijakan Leverage, Keputusan \\
Investasi, Kebijakan Dividen \\
b. Dependent Variable: Nilai perusahaan
\end{tabular}

Sumber: Data Olahan (2019)

\section{Hasil Uji Heteroskedastisitas}

Pada Gambar 2 terlihat bahwa titik-titik menyebar secara acak dan tidak membentuk suatu pola tertentu, serta tersebar di atas dan di atas angka nol pada sumbu Y. Dengan demikian dapat disimpulkan bahwa model regresi dalam penelitian ini bebas dari heteroskedastisitas. 


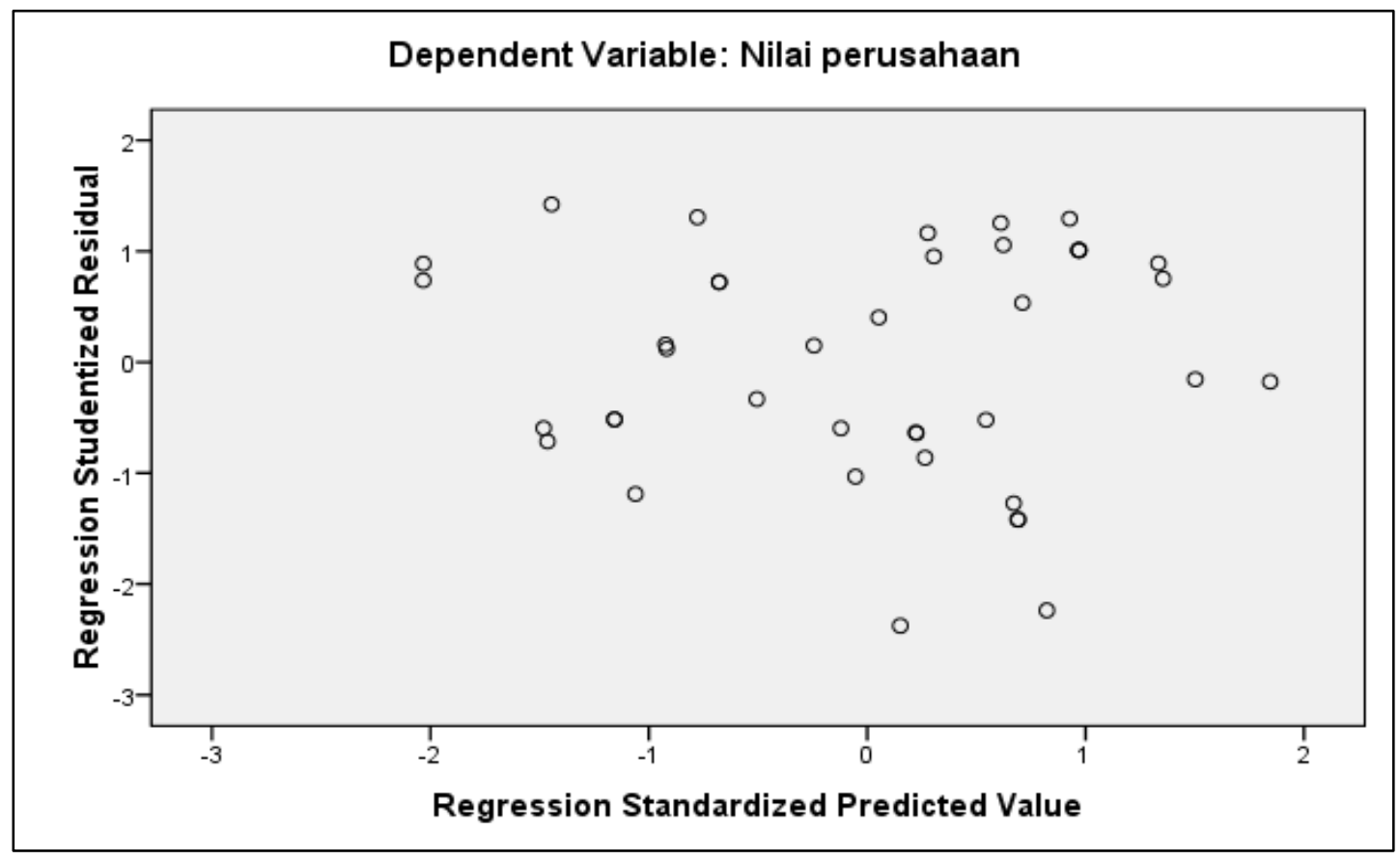

Gambar 2. Uji Heteroskedastisitas (Sumber: Data Olahan, 2019)

\section{Regresi Linear Berganda}

Hasil perhitungan regresi linear berganda dapat di lihat pada Tabel 9.

Tabel 9. Uji Regresi Linear Berganda

\begin{tabular}{llrrr}
\hline & \multicolumn{2}{c}{ Coefficients $^{\mathbf{a}}$} & \\
\hline & \multicolumn{2}{c}{$\begin{array}{c}\text { Unstandardized } \\
\text { Coefficients }\end{array}$} & $\begin{array}{c}\text { Standardized } \\
\text { Coefficients }\end{array}$ \\
\cline { 2 - 5 } Model & \multicolumn{1}{c}{ B } & Std. Error & Beta & \\
\hline $1 \quad$ (Constant) & 11.142 & 1.590 & .697 \\
$\begin{array}{l}\text { Kebijakan Dividen } \\
\text { Kebijakan }\end{array}$ & .739 & .608 & .579 \\
$\begin{array}{l}\text { Leverage } \\
\begin{array}{l}\text { Keputusan } \\
\text { Investasi }\end{array}\end{array}$ & .662 & .559 & .331 \\
Manajemen Laba & .496 & .317 & .283 \\
\hline
\end{tabular}

a. Dependent Variable: Nilai perusahaan

Sumber: Data Olahan (2019)

Berdasarkan hasil uji regresi linear berganda pada Tabel 9, diperoleh persamaan regresi sebagai berikut:

$$
Y=11.142+0.739 X 1+0.662 X 2+0.496 X 3+0.267 X 4
$$

Berdasarkan persamaan regresi di atas, maka dapat dijelaskan:

a. Konstanta sebesar 11.142 menyatakan bahwa jika diasumsikan bahwa variabel kebijakan dividen (X1), kebijakan leverage (X2), keputusan investasi (X3) dan 
manajemen laba (X4) adalah konstan, maka nilai perusahaan pada perusahaan pertambangan yang terdaftar di BEI Tahun 2015-2018 adalah sebesar 11.142.

b. Koefisien regresi sebesar 0.739 menyatakan bahwa setiap penambahan 1 nilai pada variabel kebijakan dividen (X1), maka akan meningkatkan nilai perusahaan pada perusahaan pertambangan yang terdaftar di BEI Tahun 20152018 sebesar 0.739 dengan asumsi besarnya variabel independen lainnya adalah tetap.

c. Koefisien regresi sebesar 0.662 menyatakan bahwa setiap penambahan 1 nilai pada variabel kebijakan leverage (X2), maka akan meningkatkan nilai perusahaan pada perusahaan pertambangan yang terdaftar di BEI Tahun 20152018 sebesar 0.662 dengan asumsi besarnya variabel independen lainnya adalah tetap.

d. Koefisien regresi sebesar 0.496 menyatakan bahwa setiap penambahan 1 nilai pada variabel keputusan investasi (X3), maka akan meningkatkan nilai perusahaan pada perusahaan pertambangan yang terdaftar di BEI Tahun 20152018 sebesar 0.496 dengan asumsi besarnya variabel independen lainnya adalah tetap.

e. Koefisien regresi sebesar 0.267 menyatakan bahwa setiap penambahan 1 nilai pada variabel manajemen laba (X4), maka akan meningkatkan nilai perusahaan pada perusahaan pertambangan yang terdaftar di BEI Tahun 2015-2018 sebesar 0.267 dengan asumsi besarnya variabel independen lainnya adalah tetap.

\section{Hasil Uji Koefisien Determinasi}

Hasil uji koefisien determinasi (R2) dapat dilihat pada Tabel 10. Berdasarkan Tabel 10 dapat dilihat bahwa nilai Adjusted R Square sebesar 0.751 atau sebesar $75,1 \%$. Hal ini menunjukkan bahwa secara keseluruhan variabel kebijakan dividen (X1), kebijakan leverage (X2), keputusan investasi (X3) dan manajemen laba (X4) memberikan sumbangan pengaruh terhadap nilai perusahaan pada perusahaan pertambangan yang terdaftar di BEI tahun 2015-2018 sebesar 75,1\%, sedangkan sisanya sebesar $24,9 \%$ dipengaruhi oleh variabel lain yang tidak di teliti dalam penelitian ini.

Tabel 10. Hasil Uji Koefisien Determinasi (R2)

\begin{tabular}{|c|c|c|c|c|}
\hline \multicolumn{5}{|c|}{ Model Summary } \\
\hline Model & $\mathbf{R}$ & R Square & Adjusted R Square & Std. Error of the Estimate \\
\hline 1 & $.873^{a}$ & .762 & .751 & .131505 \\
\hline \multicolumn{5}{|c|}{$\begin{array}{l}\text { a. Predictors: (Constant), Manajemen Laba, Kebijakan Leverage, Keputusan } \\
\text { Investasi, Kebijakan Dividen }\end{array}$} \\
\hline Depe & t Variab & le: Nilai per & usahaan & \\
\hline
\end{tabular}




\section{Hasil Pengujian Hipotesis}

\section{Hasil Uji Hipotesis Pertama}

Hasil pengujian hipotesis pertama dapat dilihat pada Tabel 11. Dari Tabel 11 dapat dilihat bahwa variabel kebijakan dividen (X1) dengan nilai t hitung $5.921>t$ tabel 2.03011 atau sig sebesar $0.000<0.05$ yang berarti $\mathrm{H} 1$ diterima dan Ho ditolak. Dengan demikian dapat disimpulkan bahwa variabel kebijakan dividen (X1) berpengaruh terhadap nilai perusahaan.

Tabel 11. Hasil Uji Hipotesis Pertama

\begin{tabular}{ccccc}
\hline Variabel Independen & $\mathbf{t}_{\text {hitung }}$ & $\mathbf{t}_{\text {tabel }}$ & Sig & Keterangan \\
\hline Kebijakan dividen $\left(\mathrm{X}_{1}\right)$ & 5,921 & 2,03011 & 0.000 & Berpengaruh
\end{tabular}

a. Dependent Variable: Nilai perusahaan

Sumber: Data Olahan (2019)

Bird in Hand Theory menyatakan berasumsi bahwa biaya modal sendiri akan naik sebagai akibat penurunan pembayaran dividen. Harga saham dipengaruhi oleh tingkat pertumbuhan dividen. Dengan kata lain, besarnya dividen yang dibayarkan akan meningkatkan nilai perusahaan. selanjutnya, pemberian dividen memberikan informasi atau isyarat mengenai kinerja finansial perusahaan terhadap pandangan para investor. Jika perusahaan memiliki rasio pembayaran dividen yang stabil atau bahkan tinggi, maka akan dapat melahirkan sentimen positif kepada para investor yang dapat meningkatkan harga saham perusahaan.

Hasil penelitian ini sejalan dengan hasil penelitian yang dilakukan oleh Martikarini (2013), Herawati (2013), dan Wahyuni et al. (2013) yang menyatakan bahwa kebijakan dividen berpengaruh terhadap nilai perusahaan.

\section{Hasil Uji Hipotesis Kedua}

Hasil pengujian hipotesis kedua dapat dilihat pada Tabel 12. Dari Tabel 12 dapat dilihat bahwa variabel kebijakan leverage $\left(\mathrm{X}_{2}\right)$ dengan nilai $t$ hitung $5.048>t$ tabel 2.03011 atau sig sebesar $0.002>0.05$ yang berarti $\mathrm{H}_{2}$ diterima dan $\mathrm{Ho}$ ditolak. Dengan demikian dapat disimpulkan bahwa variabel kebijakan leverage $\left(\mathrm{X}_{2}\right)$ berpengaruh terhadap nilai perusahaan.

Tabel 12. Hasil Uji Hipotesis Kedua

\begin{tabular}{ccccc}
\hline Variabel Independen & $\mathbf{t}_{\text {hitung }}$ & $\mathbf{t}_{\text {tabel }}$ & Sig & Keterangan \\
\hline Kebijakan leverage $\left(\mathrm{X}_{2}\right)$ & 5,048 & 2,03011 & 0.002 & Berpengaruh \\
\hline
\end{tabular}

a. Dependent Variable: Nilai perusahaan

Sumber: Data Olahan (2019)

Signalling theory menyatakan bahwa perusahaan yang mampu menghasilkan keuntungan cenderung akan meningkatkan hutangnya karena tambahan bunga yang dibayarkannya akan diimbangi dengan laba sebelum pajak. Penggunaan leverage mampu meningkatkan nilai perusahaan karena dalam perhitungan pajak, bunga yang dikenakan akibat penggunaan hutang dikurangkan terlebih dahulu, sehingga mengakibatkan perusahaan akan memperoleh keringanan pajak. 
Hasil penelitian ini sejalan dengan hasil penelitian yang dilakukan oleh Rika Puspa Ayu dan Emrinaldi (2017), Sholichah dan Andayani (2015), serta Pratama dan Wiksuana (2016) yang menyatakan bahwa kebijakan leverage berpengaruh terhadap nilai perusahaan.

\section{Hasil Uji Hipotesis Ketiga}

Hasil pengujian hipotesis ketiga dapat dilihat pada Tabel 13. Dari Tabel 13 dapat dilihat bahwa variabel keputusan investasi $\left(X_{3}\right)$ dengan nilai $t$ hitung $4.674>t$ tabel 2.03011 atau sig sebesar $0.018<0.05$ yang berarti $\mathrm{H}_{3}$ diterima dan $\mathrm{H}_{0}$ ditolak. Dengan demikian dapat disimpulkan bahwa variabel keputusan investasi $\left(X_{3}\right)$ berpengaruh terhadap nilai perusahaan.

Tabel 13. Hasil uji hipotesis ketiga

\begin{tabular}{ccccc}
\hline Variabel Independen & $\mathbf{t}_{\text {hitung }}$ & $\mathbf{t}_{\text {tabel }}$ & Sig & Keterangan \\
\hline Keputusan investasi $\left(X_{3}\right)$ & 4,674 & 2,03011 & 0.018 & Berpengaruh \\
\hline
\end{tabular}

a. Dependent Variable: Nilai perusahaan

Sumber: Data Olahan (2019)

Signalling theory menyatakan bahwa pengeluaran investasi memberikan sinyal positif terhadap pertumbuhan perusahaan dimasa yang akan datang, sehingga meningkatkan harga saham sebagai indikator nilai perusahaan. Dengan kata lain, bila dalam berinvestasi perusahaan mampu menghasilkan keuntungan dengan menggunakan sumber daya perusahaan secara efisien, maka perusahaan akan memperoleh kepercayaan dari calon investor untuk membeli sahamnya. Peningkatan harga saham inilah yang jadi indikator bahwa nilai perusahaan juga meningkat.

Hasil penelitian ini sejalan dengan studi yang dilakukan oleh Ayem dan Nugroho (2016), Afzal dan Rohman (2012), dan Tri Wahyuni (2013) yang menyatakan bahwa keputusan investasi berpengaruh terhadap nilai perusahaan.

\section{Hasil Uji Hipotesis Keempat}

Hasil pengujian hipotesis keempat dapat dilihat pada Tabel 14. Dari Tabel 14 dapat dilihat bahwa variabel manajemen laba $\left(\mathrm{X}_{4}\right)$ dengan nilai $\mathrm{t}$ nitung $2.124>\mathrm{t}$ tabel 2.03011 atau sig sebesar $0.032<0.05$ yang berarti $\mathrm{H}_{4}$ diterima dan $\mathrm{H}_{0}$ ditolak. Dengan demikian dapat disimp ulkan bahwa variabel manajemen laba $\left(\mathrm{X}_{4}\right)$ berpengaruh terhadap nilai perusahaan.

Tabel 14. Hasil uji hipotesis keempat

\begin{tabular}{lcccl}
\hline Variabel Independen & $\mathbf{t}_{\text {hitung }}$ & $\mathbf{t}_{\text {table }}$ & Sig & Keterangan \\
\hline Manajemen laba $\left(\mathrm{X}_{4}\right)$ & 2,124 & 2,03011 & 0.032 & Berpengaruh \\
\hline \multicolumn{7}{l}{ a. Dependent Variable: Nilai perusahaan } \\
Sumber: Data olahan (2019)
\end{tabular}

Agency theory berasumsi bahwa setiap individu semata-mata termotivasi oleh kepentingan pihak manajemen sendiri sehingga menimbulkan konflik kepentingan antara principal dan agen. Masalah keagenan muncul karena adanya perilaku oportunistik dari agen, yaitu perilaku manajemen untuk memaksimumkan 
kesejahteraannya sendiri yang berlawanan dengan kepentingan pemilik. Laporan keuangan digunakan oleh principal untuk memberikan kompensasi kepada manajemen, hal ini dapat dimanfaatkan manajemen untuk mendapatkan keuntungan lebih besar dengan cara melakukan pencatatan akuntansi secara accrual basis yang merupakan objek manajerial discretion. Hasil penelitian ini sejalan dengan hasil penelitian yang dilakukan oleh Jefriansyah (2015), Susanto dan Christiawan (2016), serta Ridwan dan Gunardi (2013) yang menyatakan bahwa manajemen laba berpengaruh terhadap nilai perusahaan.

\section{KESIMPULAN}

Berdasarkan hasil penelitian dan pembahasan diatas, maka dapat ditarik kesimpulan kebijakan dividen berpengaruh terhadap nilai perusahaan. Hal ini dikarenakan kebijakan ini berkaitan dengan penentuan pembagian pendapatan pada suatu perusahaan, sehingga besarnya dividen yang dibayarkan akan meningkatkan nilai suatu perusahaan.

Kebijakan leverage berpengaruh terhadap nilai perusahaan. Hal ini dikarenakan kebijakan leverage yang diambil oleh pihak manajemen merupakan sumber pembiayaan bagi perusahaan sehingga dapat digunakan dalam operasional perusahaan. Semakin tinggi tingkat leverage suatu perusahaan maka nilai perusahaan akan mengalami kenaikan. Sebaliknya, jika leverage suatu perusahaan berkurang maka nilai perusahaan akan mengalami penurunan.

Keputusan investasi berpengaruh terhadap nilai perusahaan. Hal ini dikarenakan adanya keputusan investasi ini memberi sinyal positif terhadap pertumbuhan perusahaan dimasa mendatang. Dengan adanya investasi, maka saham perusahaan akan lebih diminati oleh investor dan meningkatkan harga saham. Suatu investasi dikatakan menguntungkan jika investasi tersebut membuat pemodal menjadi kaya.

Manajemen laba berpengaruh terhadap nilai perusahaan. Hal ini dikarenakan tindakan manajer yang meningkatkan atau menurunkan laba yang dilaporkannya dianggap mampu menumbuhkan minat investor untuk menginvestasikan sahamnya terhadap suatu perusahaan. 


\section{DAFTAR PUSTAKA}

(1) Afzal, A., \& Rohman, A. (2012). Pengaruh Keputusan Investasi, Keputusan Pendanaan dan Kebijakan Dividen terhadap Nilai Perusahaan. Diponegoro Journal of Accounting, 1(1), 492-500. https://ejournal3.undip.ac.id/index.php/accounting/article/view/560

(2) Ayem, S., \& Nugroho, R. (2016). Pengaruh Profitabilitas, Struktur Modal, Kebijakan Dividen dan Keputusan Investasi terhadap Nilai Perusahaan. Jurnal Akuntansi, 4(1), 31-40. http://jurnalfe.ustjogja.ac.id/index.php/akuntansi/article/view/125

(3) Ayu, R.P., \& Emrinaldi. (2017). Pengaruh Kinerja Keuangan terhadap Nilai Perusahaan dengan Kebijakan Dividen sebagai Faktor Pemoderasi Bank Pembangunan Daerah Tahun 2001-2011. Jurnal Tepak Manajemen Bisnis, 9(1), 751-771. https://jtmb.ejournal.unri.ac.id/index.php/JTMB/article/view/5614

(4) Brigham, E.F., \& Houton, J.F. (2011). Dasar-dasar manajemen keuangan terjemahan. Edisi 10. Jakarta, Indonesia: Salemba Empat.

(5) Brigham, E.F., \& Houton, J.F. (2014). Dasar-dasar manajemen keuangan. Jakarta, Indonesia: Salemba Empat.

(6) Fauzi, Y. (2017, May 4). Ekonomi tumbuh, industri tambang malah melorot. Retrieved from http://www.cnnindonesia.com/ekonomi/20170505144748-85-212583/ekonomitumbuh-industri-tambang-malah-melorot

(7) Fischer, M., \& Rosenzweig, K. (1995). Attitudes of Student and Accounting Practitioners Concerning the Ethical Acceptability of Earnings Management. Journal of Business Ethics, 14(6), 433-444.

(8) Gewati, M. (2016, December 15). Industri tambang global dan nasional ada di ujung tanduk. Retrieved from http://ekonomi.kompas.com./read/2016/12/15/124400126/industri.tambang.global.dan. nasional.ada.di.ujung.tanduk

(9) Hartomo, G. (2019, January 9). Tidak ada investor baru di sektor tambang, begini penjelasan KESDM. Retrieved from https://economy.okezone.com/read/2019/01/09/320/2002070/tak-ada-investor-baru-disektor-tambang-begini-penjelasan-kesdm

(10) Herawati, T. (2013). Pengaruh Kebijakan Dividen, Kebijakan Hutang dan Profitabilitas terhadap Nilai Perusahaan. Jurnal Manajemen, 2(2), 1-18.

(11) Herliansyah, Y. (2012). Modul Seminar: Akuntansi Pertambangan Umum Seminar Akuntansi. Jakarta, Indonesia: Pusat Pengembangan Bahan Ajar, Universitas Mercu Buana.

(12) Ika, A. (2016, September 13). Sektor Pertambangan Terpuruk, IHSG Ditutup Turun 66,35 Poin. Retrieved from https://money.kompas.com/read/2016/09/13/164438626/sektor.pertambangan.terpuruk insg.ditutup.turun.66.35.poin

(13) Jefriansyah. (2015). Pengaruh Kebijakan Hutang dan Manajemen Laba terhadap Nilai Perusahaan (Studi Empiris pada Perusahaan Manufaktur yang Terdaftar di BEI). Jurnal Akuntansi, 3(1), 1-21. http://ejournal.unp.ac.id/students/index.php/akt/article/view/1619

(14) Jensen, M.C., \& Meckling, W.H. (1976). Theory of the firm: Managerial behavior, agency costs and ownership structure. Journal of Financial Economics, 3(4), 305-360. https://doi.org/10.1016/0304-405X(76)90026-X

(15) Lintner, J. (1956). Distribution of Incomes of Corporations Among Dividends, Retained Earnings, and Taxes. The American Economic Review, 46(2), 97-113.

https://www.jstor.org/stable/1910664 
(16) Manurung, A.H. (2012). Teori Keuangan Perusahaan. Jakarta, Indonesia: PT Adler Manurung Press.

(17) Martikarini, N, 2013. Pengaruh profitabilitas, kebijakan hutang, dan dividen terhadap nilai perusahaan manufaktur yang terdaftar di Bursa Efek Indonesia periode 20092011(Undergraduate Thesis). Fakultas Ekonomi, Universitas Gunadarma, Depok, Jawa Barat, Indonesia.

(18) Martono, \& Harjito, A. (2010). Manajemen keuangan. Yogyakarta, Indonesia.:

(19) Pratama, I.G.B.A, \& Wiksuana, I.G.B. (2016). Pengaruh Ukuran Perusahaan dan Leverage terhadap Nilai Perusahaan dengan Profitabilitas sebagai Variabel Mediasi. E-Jurnal Manajemen, 5(2), 1338-1367.

https://ojs.unud.ac.id/index.php/Manajemen/article/view/17498.

(20) Ridwan, M., \& Gunardi, A. (2013). Peran Mekanisme Corporate Governance Sebagai Pemoderasi Praktik Earning Management Terhadap Nilai Perusahaan. Trikonomika, 12(1), 49-60.

(21) Riyanto, B. (2011). Dasar-dasar Pembelanjaan Perusahaan. Yogyakarta, Indonesia: BFEE Yogyakarta.

(22) Sartono, A. (2010). Manajemen Keuangan: Teori dan Aplikasi. Yogyakarta, Indonesia: BFEE Yogyakarta.

(23) Schipper, K. (1989). Earning Management. Accounting Horizons, 394), 91-102.

(24) Sholichah, W.A., \& Andayani. (2015). Pengaruh Struktur Kepemilikan, Ukuran Perusahaan dan Leverage terhadap Nilai Perusahaan. Jurnal IImu dan Riset Akuntansi, 4(10).

(25) Susanto, S., \& Christiawan, Y.J. 2016. Pengaruh Earnings Management terhadap Firm Value. Business Accounting Review, 4 (1), 205-216. http://publication.petra.ac.id/index.php/akuntansi-bisnis/article/view/4124

(26) Wahyuni, T., Ernawati, E., \& Murhadi, W.R. (2013). Faktor-faktor yang Mempengaruhi Nilai Perusahaan di Sektor Property, Real Estate \& Building Construction yang Terdaftar di BEI Periode 2008-2012. CALIYPTRA: Jurnal IImiah Mahasiswa Universitas Surabaya, 2(1), 1-18.

https://journal.ubaya.ac.id/index.php/jimus/article/view/380

(27) Wijaya, L.R.P., Wibawa, A. (2010, October 13). Pengaruh Keputusan Investasi, Keputusan Pendanaan Dan Kebijakan Dividen Terhadap Nilai Perusahaan. Paper presented at Simposium Nasional Akuntansi XIII Purwokerto, Purwokerto, Indonesia. 